\title{
Regulatory Role of TQM between the Marketing Orientation, Entrepreneurial Orientation and the Organizational Performance and Competitiveness
}

\author{
Abdulrahman Alsughayir \\ Business School, Al Imam Muhammad ibn Saud University, Riyadh, Saudi Arabia \\ Email: aaalsughayir@yahoo.com
}

Received 5 January 2016; accepted 28 May 2016; published 31 May 2016

Copyright (C) 2016 by author and Scientific Research Publishing Inc.

This work is licensed under the Creative Commons Attribution International License (CC BY). http://creativecommons.org/licenses/by/4.0/

(c) (i) Open Access

\section{Abstract}

This review is aiming to investigate the integration of people, planning and process in a Total quality management (TQM) setting prompting organizational performance and their competitiveness. In order to compete for a good market position, organizations need to implement effective management strategies such as TQM. The term TQM is explained as "managing the entire organization so that it excels in all dimensions of products and services that are important to the customer". However, TQM model goes beyond product, process and service quality. The objective of this review is to develop an understanding of TQM and its possible influence on organizational performance and competitiveness. This review will be looking at entrepreneurial orientation (E0), market orientation (MO), and organizational competitiveness attributes. As quality is a mixture of many interconnected efficiencies that makes the difference at the end. Likewise, quality is an organization's first step towards market competitiveness. EO is an important factor which could lead to various advantages and added value if adequately implemented in the organization with other supportive strategic management initiatives. It is identified that the problem of organizations not accomplishing the anticipated performance through EO and MO is due to the deficiency of organizational inappropriate schemes and worthless practices. In addition, EO as alone is insufficient resource to enhance performance and achieve competitive advantages. In addition, organizational internal resources (resource base view (RBV)) are important for organizational performance. Continuous premium quality leads organizations to avail sustainable competitive position in the market. TQM, EO (internal resources) and MO (external resources) contribute to organizational intangible capabilities that lead organizations to achieve their desired performance and competitiveness. This review will look into and conceptually find why even there are sufficient literature on TQM, EO and MO available, but still the previous research have unable to provide a unambiguous and strategic avenues for practitioners to accept. 


\section{Keywords}

\section{Entrepreneurial Orientation (EO), Market Orientation (MO), Organizational Performance and Competitiveness}

\section{Total Quality Management}

The phenomenon of total quality management (TQM) in organization is a deep-rooted theory which is identified and recognized to be very important for the guidance and to analyze business quality and productivity related issues. These issues were addressed by previous research [1]-[6] via a theoretical framework to understand the quality and productivity related issues and helping organization to concentrate only on the key problems when the concern is only to improve the quality, productivity and performance. Nadarajah and Latifah [7] have noted that continuous improvement for organization become an important matter for organizations. In the same context TQM is being debated for more than two decades by frequent researchers such as Edwards Deming, Joseph Juran, Philip Crosby and Kaoru Ishikawa for the aim to find a way out for organizational to continuously improve their productivity and performance to successfully suite their customers. According to the International Academy of the American Society for Quality (IAASQ) has defined TQM as:

"The management approach of an organization centered on quality, based on the participation of all of its members and aiming at long-term success through customer satisfaction and benefits to all members of the organization and to society." [2].

TQM might be explained as an incessant struggle for quality improvement and excellence by producing the correct set of approaches and skills in employees to make it at level best to avoid defects and satisfy the end customers regularly, Lakhe and Mohanty [8] and Oakland [9] explained TQM as:

"Total Quality Management (TQM) is an approach to improving the effectiveness and flexibility of business as a whole. It is essentially a way of organizing and involving the whole organization; every department, every activity, every single person at every level."

In addition, Zaire and Simintiras [10] defined TQM as:

"Total Quality Management is the combination of the socio-technical process towards doing the right things (externally), everything right (internally) first time and all the time, with economic viability considered at each stage of each process."

Some of the common examples of continuous process improvement approach are TQM. TQM are initiatives which enable organization's process improvement initiatives and this is due to inadequacies reported in their productivity or performance [2] [10] [11], business process management (BPR) [12] and etc.

Previous research on the impact of TQM on organizational performance exclusively concentrate on firm's resources (theory of resource base view (RBV)) [13], theory of competitive advantage (such as Porter's competitive Wheel, Diamond) (Bakan \& Doğan [14]; Bridoux [15] and System theory (Belogolovsky \& Bamberger [16]). On the similar note, [10] aimed to investigate the many frequently cited Gurus and researchers who have contributed significantly to TQM in term of practice and theory in previous 10 decades. His findings suggested that TQM can be debated, but the theory and its expanded attributes have significantly contributed to the quality and productivity excellence in the industry. The author have suggested, that what is important is the TQM thinking, and that is the reason there are mange researchers who have addressed the difficulties and prospects that TQM offers. The credibility of TQM is no longer challenged and cannot be examined at all since it has been established in many countries in the world, that competitive advantages can be created and continued by obeying through the acceptance of TQM thinking. For example, countries like, the USA has improved its competitive position by inspiring the adoption of TQM thinking, not just in the private sector but also in government services and the public sector as a whole. Similarly, Japan has ruled the world's economy for over 50 years by transforming its industry on TQM based thinking.

The study of TQM and business performance points out the presence of an essential association concerning the two. For example [6], conducted a study in Greek on 90 food companies, and found that the dualistic perspective of TQM (i.e. hard and soft TQM) in food companies have a different set of finding. The soft perspective of TQM have a significant effect on worker benefits, quality improvement and customer satisfaction. On the other 
hand, the hard perspective of TQM have an indirect impact on quality improvement. The authors have concluded that quality improvement is also a noteworthy feature that directly influences business performance. In addition, a study was conducted on 99 service organizations in Sri Lanka by Yapa [16], and found that there is an enthusiasm among managers in implementing TQM in their organizations. 41 percent of the organizations have realized the importance of TQM and the importance of implementing TQM in their organization. It is also revealed that there is a contradiction and of lack of understanding of TQM ideology and procedures between the managers. Consequently, there is a requirement for introduction of TQM related small training programs by training institutes and universities. Another approach might be the introduction of TQM related programs in to the MBA and BBA degree programmes. Furthermore, a study conducted by Harrington et al. [2] to investigate the productivity and quality problems and rooms for improvement found that there has been a slow variation over from quality control (QC) to TQM in construction industry.

Apart from all the positive things about TQM, there are some problems in implementing TQM in organizations. For instance, [8] discussed a case of a TQM application in a firm in Bombay, India. They found that biggest issue in implementing TQM, particularly in developing country is firstly insufficient knowledge and info about TQM; secondly, uncertainties of workforces about management's intentions; thirdly, failure of management to maintain commitment and interest over a long term period; fourthly, difficulty in gauging the usefulness of TQM; fifthly, poor internal communication; sixthly, difficulty in measuring customer prospects and satisfaction; and lastly, inadequate training resources.

On the similar note, a research was conducted on 41 Indian quality award winning industries by Bhat and Rajashekhar [17], found that the barriers of TQM implementation, is that there is no benchmarking of other firm's employees and practices and are resistant to transformation in these industries. Similarly, Mosadeghrad [18], also investigated the barriers to TQM successful implementation by critically review 54 empirical studies on TQM found 54 issues to effectively implement TQM. It is found that there is an ineffectual TQM package, unsuitable TQM execution methods and an unsuitable environment for executing TQM are the underpinned motives for TQM failure. However, the author have also found that TQM implementation failures can also be due to inadequate training and education, absence of workers' involvement, deficiency of top management livelihood, insufficient resources, poor leadership, deficiency of a quality oriented culture, deprived communication, shortage of a plan for transformation and worker opposition to the change.

Pinho [5] aimed to investigate the synergistic relationships between TQM and performance. The author used 1200 Portuguese manufacturing SMEs secondary data taken from the Dun \& Bradstreet and EXPOENTE (Portuguese consultancy firm) databases. It was exposed that there is a substantial relationship between TQM components and SME performance. The inclusive association for organization was that orientations allocated a strong grounds for building significant competitive advantage and consistence performance. In addition, Joiner [19] conducted a study on motor vehicle parts and accessories industry, found a positive significant association concerning the degree of implementation of organization performance and TQM practices. On the similar note, Talib et al. [20], after doing a comprehensive literature review came to know that for Indian service sector firm's TQM and quality performance could help management and managers for efficient decision making and enhance their organizational performance.

\section{Entrepreneurial Orientation}

Figure 1 which has been adapted from [21] EO has been associated with organizational performance, Previously, Entrepreneurial orientation (EO) is well elaborated by researchers as the portion of firm level entrepreneurship. EO has been related with OP, whereby the greater the EO, the greater the level of performance. In addition, EO is defined as the ideology which explains "how a new entry is undertaken", it is a consideration of how a firm operates. EO is a firm level variable. In addition, [21], conducted a study on 111 respondents from Dubai police department found a significant influence of EO and TQM on organizational performance. It is also revealed that TQM partially mediates between EO and organizational performance.

The findings of this study showed that organizations should always take into consideration that before planning to implement any strategy or new practices, they have to develop the supportive culture. Without the supportive culture, any organizational changes can be deemed a failure. In addition, TQM can help entrepreneurial organizations to gain the competitive advantage that differentiate the organization from its rivals and enhance its market position. 


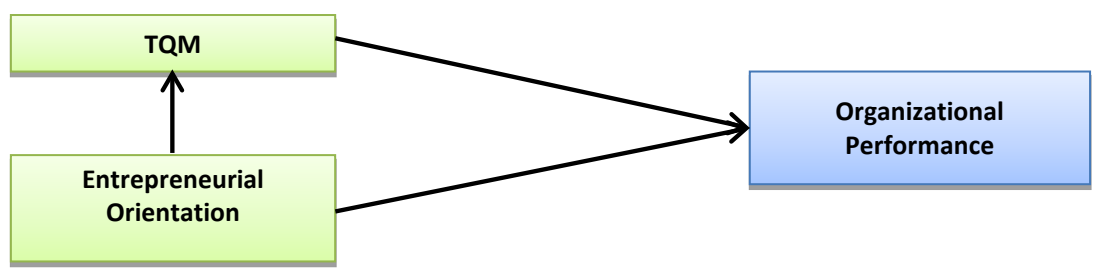

Figure 1. EO has been associated with organizational performance.

Baba [22], conducted a study on 101 SMEs in Labuan. The author investigated the association between EO dimensions (autonomy, risk taking, competitive aggressiveness, innovation, pro-activeness), and organizational performance (customer performance, product performance and sales growth), explored that SMEs risk taking, aggressiveness and pro-activeness have significant association with OP. The author discussed that it might be due to the organization involvement in this study are micro and small, therefore these organizations are operated in autocratic way to make sure survival. Furthermore, [23] conducted a study on 124 executives from 94 firm, found that there are dual dissimilar approaches to entrepreneurial decision making that may have dissimilar influence on organization performance. These dissimilarities are specifically due to the way how firms associated to the external environment. The authors have further indicated that the dimension of EO most of the time vary independently somewhat than co-vary. This suggested that the degree to which an entrepreneurial approach to strategy building is beneficial will often depend on the environmental or organizational conditions underneath which such choices are made. Al-Swidi and Mahmood [24] also conducted a study on 201 samples from bank managers in Yemen, found organizational culture moderates the relationship between TQM, EO and OP. They further explained the phenomenon by informing that among the bank there are lack of efficiency and these banks are not customer or market focused. In addition to that, Yemeni banks' managers lack the entrepreneurial abilities to take the benefit of the obtainable business opportunities.

In addition, Amin [25], conducted a study on Saudi Arabian electronic and electrical sector's 200 SMEs and 250 food and beverage SMEs found EO's dimensions such as risk taking, innovativeness and pro-activeness have a significant connections with SMEs' performance. Similarly, [22] conducted a study on SMEs, noted that sub dimension of EO such as risk taking, innovation, pro-activeness and competitive aggressiveness have significant association with organizational performance. Furthermore, Wiklund and Shepherd [26], conducted a study on Swedish incorporated companies, noted that EO appreciates OP, but their analysis noted that empirical finding are mixed. Their finding suggested that small and medium businesses facing critical restrictions in terms of financial limitations and a consistent environment benefit the most by acquiring an EO. In a simplified understanding, EO is not the luxury of firms during high growth with limited financial capital, but EO could be utilized to overcome resource and environmental restrictions. They informed that frankly speaking these firm in these situations can perform better if they have more EO as stated in Figure 2.

\section{Market Orientation}

Hassim et al. [27], conducted a study on 398 SMEs in Malaysia, found that innovativeness and EO have a positive significant influence on OP. On the other hand, the authors have noted a negative influence of MO on OP.

The authors further revealed that external environmental factors do have a moderating influence on the association between MO and OP. They suggested that the entrepreneurs of how their EO, MO and organizational innovations could impact their OP. EP is positively and significantly connected to MO and it is known as an important input to MO. For SME, EO is more proactive with some specific market intelligence to look at the existing market opportunities. MO also positively impact the innovation behaviour as it encourages the organisation to seek addition knowledge in order to expand, improve and change the existing business processes, services and production. In addition, external environment factors do have a moderating influence on the relationship between MO and OP. The market instability, competition intensity and technological capabilities elements of the environmental factors do have an important influence on the MO and OP association as stated in Figure 3.

\section{Market Orientation and Organizational Performance}

Kwon [28] conducted a study on 168 Korean multinational companies (MNC) subsidiaries operating in China 


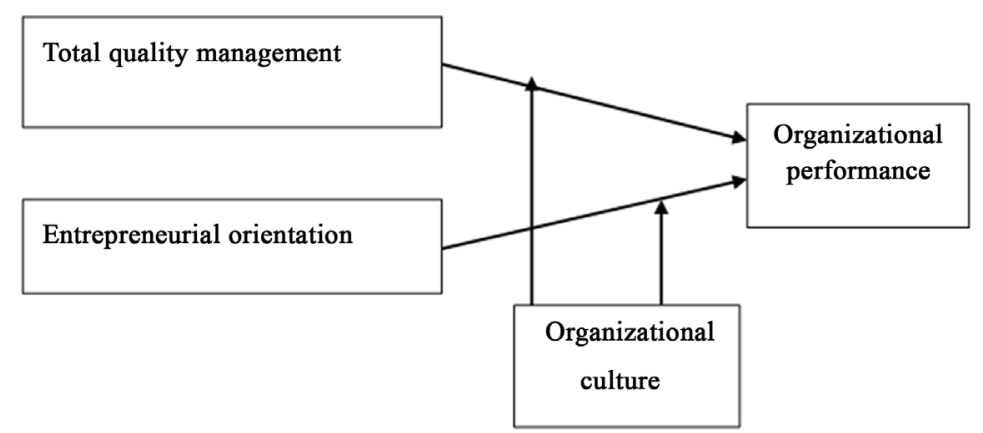

Figure 2. The role of organizational culture and organizational performance. Al-Swidi and Mahmood (2012).

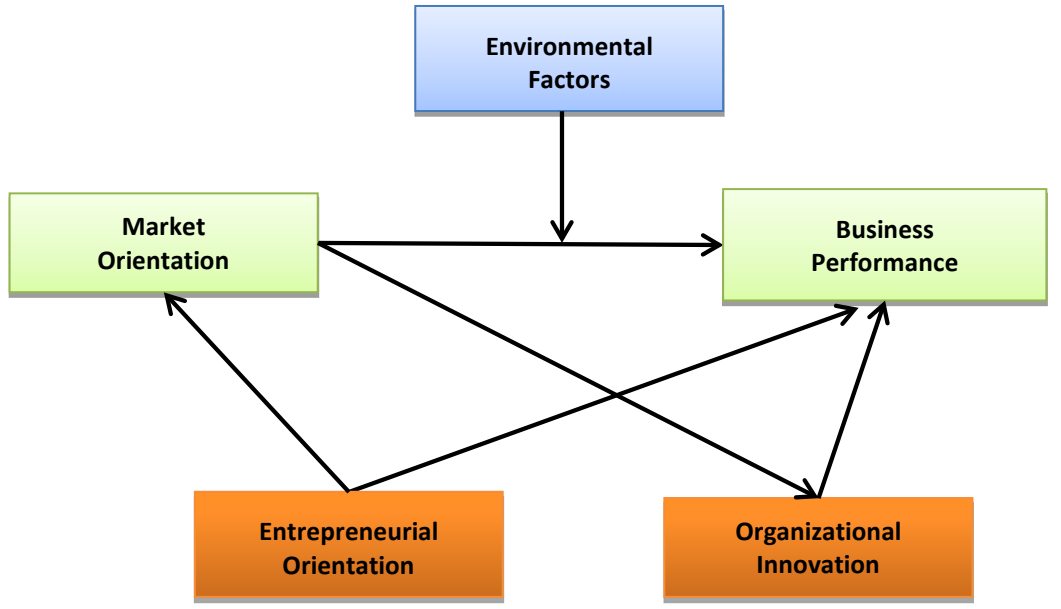

Figure 3. The effects of entrepreneurial orientation on firm organisational innovation and market orientation towards firm business performance. Hassim, Nizam, Talib, \& Bakar (2011).

and India found that the role market orientation is significant in foreign subsidiary performance. The author, noted that foreign subsidiaries, which hold greater technology advantages capabilities and keep active network associations with native key entities such as governmental authorities, suppliers, and distributors, customers, are found to actively dedicate themselves to MO. Furthermore, Shoham et al. [29], performed a meta-analysis using a quantitative approach. They summarize the empirical studies of the indirect and direct relationship influence of market orientation on three outcomes. The finding have suggested that the direct, indirect, and total influences of $\mathrm{MO}$ on OP were all significant. This might be because the managers are aggressive in strengthening and implementing a market orientation in their organizations. In addition, Gonzalez et al. [30], conducted a study on 183 firms located in the Castillay Leon region, in Spain, found that there a significant relationship between entrepreneurship and MO. Even these orientations might be executed separately, firms give emphasis to entrepreneurship in a situation when they are market driven. As a result, the strong connection and complementarities between entrepreneurship and MO decrease the struggle involved in the combined implementation of both orientations. These both orientations also showed a strong connection with performance, such that each contributes precisely. On the similar note, Green et al. [31], conducted a study on 173 manufacturing organizations in U.S, found that market orientation was found to be a positive predictor of both financial and marketing performance. The author concluded that practicing managers are required not to follow a specific organizational structure in grounding for implementing a MO. On the other hand, managers required to distinguish that implementation of a MO does lead to enhanced financial and marketing performance.

\section{Market Orientation, Entrepreneurial Orientation and Organizational Performance}

In another study conducted by Gruber et al. [32] on 170 Austrian exporters found that both market-orientated 
and entrepreneurial-oriented strategies have positive performance influence in emerging markets. Therefore, the foremost contribution of their study is that market orientation and entrepreneurial orientation does have an impact on firm performance, because strategies that have been proven successfully in advanced markets can be transferred to emerging markets. However, [33] conducted a study on Kenya Wildlife Services (KWS)'s 60 employees, found that while implementing TQM the biggest change is to cascade the program at the most lowest level of the pyramid. It is the duty of management to make sure TQM responsiveness to all staff levels. They informed that in general setting firm use TQM approaches that encourage their current organizational culture thus leading to unproductive TQM enactment.

\section{Market Orientation, TQM and Organizational Performance}

However, a study carried on 141 Turkish textile manufacturers by Demirbag et al. [1], noted that MO has a significant influence on the degree of TQM execution, but the authors found no significant influence on OP. In addition the authors, have explored a significant relationship between the extent of TQM implementation and OP. The author also revealed that MO has a significant impact on OP, when TQM is mediated. It would be beneficial for SMEs to insert TQM as a management facilitating tool for enhancing OP. Similarly, a study conducted by Zelbst et al. [34], on 104 U.S based manufacturing managers, supervisors, and quality professionals. The authors found that market-orientation directly and positively influence on just-in-time (JIT), TQM, and agile manufacturing (AM). JIT positively and directly impacts TQM which in turn positively and directly impacts AM. AM positively and directly impacts both organizational and logistic (LP). The authors also revealed that the findings of the relationship between JIT and TQM have no direct effect on OP was surprising and it could be explained as JIT alone is subject to disruption from, for example, poor quality. In addition it could also be concluded that without TQM, JIT may actually negatively influence OP if inventory levels are reduced to the point where consumers do not distinguish had equate variability or products are unobtainable for purchase. Furthermore, Wang and Chen [35] conducted a study on 588 hotels in Republic of China, found that TQM has positive influence on hotel performance. Moreover, MO also impact hotel performance positively. They authors also informed that there is a mediation effect of MO between TQM and hotel performance. Their research have identified that certainly TQM has influence on Market orientation. In addition it is also found that market orientation has a mediating influence between TQM and Chinese hotels performance. Therefore, these hotels have to consider MO or TQM as a platform for enhancing hotel's performance.

\section{Market Orientation, TQM and Service Quality}

Lam, Lee, Ooi, and Phusavat, (2012), aimed to investigate the association TQM, MO and SQ in the 150 firms in Malaysian service industry. The authors found that TQM has a positive significant connection with both MO and SQ. Furthermore, it was exposed that MO is an important attribute to influence service quality. It is concluded that TQM implementation plays a significant role and it could improve the market orientation of a service companies in Malaysia.

\section{Market Orientation, Service Quality and Organizational Performance}

Similarly, a study by Pantouvakis [36] aiming to examine the impact of market orientation (MO) and service quality (SQ) logic on business performance of 400 shipping firm in Greece. The author found that apart from what is perceived by majority of manager inside and separated from maritime zone, entire shipping firms are intensely market-oriented and that SQ and business performance are thoroughly correlated to each other. In addition, Ramayah et al. [37], conducted a study on Malaysian 175 service organizations, noted that MO has an important impact on OP and service quality. However, authors noted that there is a significant influence of service quality on organization performance. Remarkably, their research found that service quality partly mediates the relationship between MO and OP (Table 1).

\section{Implication}

This review has very important implication for researchers, practioners and academicians. Firstly the above review look into entrepreneurial and market orientation towards TQM implementation. The literature have suggested that execution of TQM practices will definitely influence organizational performance. Secondly, the 
Table 1. Barriers to successful TQM implementation strategic.

\begin{tabular}{|c|c|c|c|}
\hline \multicolumn{2}{|r|}{ Strategic Barriers } & \multicolumn{2}{|r|}{ Contextual Barriers } \\
\hline- & Unjustified TQM programme & - & Inappropriate organizational culture \\
\hline- & YQM adoption barriers & - & Difficulties in changing organizational culture \\
\hline- & Unrealistic expectations & - & Lack of team orientation \\
\hline- & Deficient leadership Poor management & - & Poor and ineffective communication \\
\hline- & Lack of top management support & - & Poor coordination \\
\hline- & Management turnover & - & Lack of employee trust in senior management \\
\hline- & Middle management resistance & - & Problem solving mindset \\
\hline- & Inappropriate planning & - & Lack of innovation \\
\hline- & Lack of constancy of purpose & - & Political behaviors \\
\hline- & Lack of long-term view & - & Diversity of workforce \\
\hline- & Lack of vision and clear direction & - & Mindset barriers \\
\hline- & Conflicting goal and priorities & \multicolumn{2}{|r|}{ Procedural barriers } \\
\hline- & Placing a poor priority on quality improvement & - & Lack of process focus \\
\hline- & Experience of previous failed change initiatives & - & Lack of proper process management \\
\hline- & Lack of government support & - & Lack of customer focus \\
\hline- & Political uncertainty & - & Lack of supplier involvement \\
\hline & Human recourses barriers & - & Bureaucracy and paperwork \\
\hline- & Lack of employee interest & - & Lack of evaluation and self-assessment \\
\hline- & Lack of employee commitment and involvement & - & Incompetent change agent or quality consultant \\
\hline- & Incompetent employees & - & Ineffective corrective actions \\
\hline- & Employees resistance in change & - & Time consuming quality improvement efforts \\
\hline- & Lack of good human resources & \multicolumn{2}{|r|}{ Structural Barriers } \\
\hline- & Inadequate empowerment at all levels & - & Inappropriate organizational structure \\
\hline- & Employee shortage and increased work load & - & Lack of organizational flexibility \\
\hline- & Lack of employee training and education & - & Lack of physical system \\
\hline- & Lack of employee motivation & - & Lack of information system \\
\hline- & High employee turnover & - & Lack of financial support \\
\hline- & Lack of recognition of rewards & - & Time shortage \\
\hline
\end{tabular}

Source: adapted from Mosadeghrad, (2014).

above literature will contribute to knowledge in TQM regarding the implementing practices and relationships between EO, MO, TQM implementation and organizational performance. Thirdly, managers and management are required to focus on the TQM practices to attain better levels of satisfaction in the industry which can permit an added advantage over other industries in retaining the competitive environment. Fourthly, this review could propose organizations to look from EO, MO, TQM and OP perspective, thus these attributes could encourage employee gaining continuous improvement. Finally, in general this review has provided an important contribution in developing a better understanding of the TQM practices and quality performance. 


\section{Recommendation}

The above review recommends that an empirical evidences are required to further under the extent of TQM implementation. Therefore it is expected that the finding will hopefully prove that the greater EO, MO will enhance OP via TQM practices. It would be interesting to further test and validate the association between EO, MO and TQM. It is also recommended to test these variable from different theoretical approaches such as “Structural Equation Modeling” (SEM).

\section{Summary}

The argument came across the previous reviews is "Why would relationship exist between EO, MO, TQM and firm performance?”. Researchers assume that the theoretical underpinning behind these relationships is based on the belief that firms will gain advantage by concentrate on something unique, for instance, responsiveness synonymous to being proactive, innovativeness, and the extent of boldness such as risk taking [38] and accordingly continuously sustaining and remaining competitive. Nevertheless results on studies investigating EO, MO, TQM and OP relationship are mixed, some find positive relationship, some find it negative while and some find no relationship. This gives the sign that the connection is quite complex. So now the question is how can EO, MO, and TQM be measured? It is specified that no precise measurement tool has been famous to measure EO at any segment e.g. societal, organization or individual levels [39]. On the other hand, Al-Swidi \& Mahmood [24] have also recommended to conduct a longitudinal and case study research design to comprehensively investigate the impact of strategy implementation like EO and TQM. Though the EO measure has been noted successful, when it was associated with a performance and organization's strategic variables [40]. Based on above literature review developed in this investigation, it is identified that there is some disagreement concerning the connection between EO, MO, TQM and the organizations' performance. There are, however, many researchers such as [3]-[5] [11] that identify the existence of a positive association between a TQM and the organization's performance. On the other hand, there are many researchers such as, [22] [23] [32] [41] as well who have noted a positive association between EO, TQM and organization's performance. However, there are various researchers such as, [1] [29] [34]-[36] [42] [43] as well who have noted a positive relationship between MO, TQM and organization's performance. Similarly there are very few researchers such as, [21] [24] [32] have addressed the relationship between EO, MO, TQM and organizational performance. Therefore, on the basis of above literature we have identified that regarding the relationship between MO, EO, TQM and performance of the organization, the previous investigations did not show agreement in the results and there are found to be inconsistencies. In this exploratory literature review, it was noticed that in both organizations, the implementation of TQM practices allowed for continuous improvements at the all level of organization and it positively influences entrepreneurial orientation and market orientation.

\section{References}

[1] Demirbag, M., Koh, S.C.L., Tatoglu, E. and Zaim, S. (2006) TQM and Market Orientation’s Impact on SMEs’ Performance. Industrial Management \& Data Systems, 106, 1206-1228.

[2] Harrington, H.J., Voehl, F. and Wiggin, H. (2014) Applying TQM to the Construction Industry. The TQM Journal, 24, 352-362.

[3] Kumar, V., Grosbois, D. De, Choisne, F. and Kumar, U. (2008) Performance Measurement by TQM Adopters. The TQM Journal, 20, 209-222. http://dx.doi.org/10.1108/17542730810867236

[4] Kuruppuarachchi, D. and Perera, H.S.C. (2010) Impact of TQM and Technology Management on Operations Performance. The IUP Journal of Operations Management, IX, 23-48.

[5] Pinho, J.C. (2008) TQM and Performance in Small Medium Enterprises. International Journal of Quality \& Reliability Management, 25, 256-275. http://dx.doi.org/10.1108/02656710810854278

[6] Psomas, E., Vouzas, F. and Kafetzopoulos, D. (2014) Quality Management Benefits through the "Soft” and "Hard” Aspect of TQM in Food Companies. The TQM Journal, 26, 431-444. http://dx.doi.org/10.1108/TQM-02-2013-0017

[7] Nadarajah, D. and Latifah, S.S.A.K. (2014) A Review of the Importance of Business Process Management in Achieving Sustainable Competitive Advantage. The TQM Journal, 26, 522-531. http://dx.doi.org/10.1108/TQM-01-2013-0008

[8] Lakhe, R.R. and Mohanty, R.P. (1994) Total Quality Management Concepts, Evolution and Acceptability in Develop- 
ing Economies. International Journal of Quality \& Reliability Management, 11, 9-33.

http://www.emeraldinsight.com/doi/pdfplus/10.1108/02656719410074279

http://dx.doi.org/10.1108/02656719410074279

[9] Oakland, J.S. (1991) One Way to Delight You're Customers. Works Management, 43, 65-71.

[10] Zairi, M. (2013) The TQM Legacy-Gurus' Contributions and Theoretical Impact. The TQM Journal, 25, $659-676$. http://dx.doi.org/10.1108/TQM-06-2013-0069

[11] Yunis, M., Jung, J. and Chen, S. (2013) TQM, Strategy, and Performance: A Firm-Level Analysis. International Journal of Quality \& Reliability Management, 30, 690-714. http://dx.doi.org/10.1108/02656711311325638

[12] MendibilTelleria, K., Little, D. and MacBryde, J. (2002) Managing Processes through Teamwork. Business Process Management Journal, 8, 338-350. http://dx.doi.org/10.1108/14637150210434991

[13] Kraaijenbrink, J., Spender, J.-C. and Groen, A. (2010) The Resource-Base View: A Review and Assessment of Its Critiques. Journal of Management, 36, 349-372. http://mpra.ub.uni-muenchen.de/21442/

[14] Bakan, İ. and Doğan, İ.F. (2012) Competitiveness of the Industries Based on the Porter’s Diamand Model: An Empirical Study. IJRRAS, 11, 441-455.

[15] Bridoux, F. (2004) A Resource-Based Approach to Performance and Competition: An Overview of the Connections between Resources and Competition. Luvain, Belgium Institutet de Gestion, Universite Catholique de Louvain, (1984), 1-21. http://www.uclouvain.be/cps/ucl/doc/iag/documents/WP_110_Bridoux.pdf

[16] Belogolovsky, E. and Bamberger, P.A. (2014) Signaling in Secret: Pay for Performance and the Incentive and Sorting Effects of Pay Secrecy. Academy of Management Journal, 57, 1706-1733. http://dx.doi.org/10.5465/amj.2012.0937

[17] Bhat, K.S. and Rajashekhar, J. (2009) An Empirical Study of Barriers to TQM Implementation in Indian Industries. The TQM Journal, 21, 261-272. http://dx.doi.org/10.1108/17542730910953031

[18] Yapa, S. (2014) Total Quality Management in Sri Lankan Service Organizations. The TQM Journal, 24, 505-517. http://dx.doi.org/10.1108/17542731211270070

[19] Joiner, T.A. (2007) Total Quality Management and Performance: The Role of Organization Support and Co-Worker Support. International Journal of Quality \& Reliability Management, 24, 617-627. http://dx.doi.org/10.1108/02656710710757808

[20] Talib, F., Rahman, Z. and Qureshi, M.N. (2010) The Relationship between Total Quality Management and Quality Performance in the Service Industry: A Theoretical Model. International Journal of Business, Management and Social Sciences, 1, 113-128.

[21] Al-Dhaafri, H.S., Al-Swidi, A.K. and Yusoff, R.Z.B. (2016) The Mediating Role of Total Quality Management between the Entrepreneurial Orientation and the Organizational Performance. The TQM Journal, 28, 89-111. http://dx.doi.org/10.1108/TQM-03-2014-0033

[22] Baba, R. (2011) Entrepreneurial Orientation of SMEs in Labuan and Its Effects on Performance. FEB Working Paper Series No. 1113, Entrepreneurial.

[23] Lumpkin, G.T. and Dess, G.G. (2001) Linking Two Dimensions of Entrepreneurial Orientation to Firm Performance: The Moderating Role of Environment and Industry Life Cycle. Journal of Business Venturing, 16, 429-451. http://dx.doi.org/10.1016/S0883-9026(00)00048-3

[24] Al-Swidi, A.K. and Mahmood, R. (2012) Total Quality Management, Entrepreneurial Orientation and Organizational Performance: The Role of Organizational Culture. African Journal of Business Management, 6, 4717-4727.

[25] Amin, M. (2015) The Effect of Entrepreneurship Orientation and Learning Orientation on SMEs’ Performance: An SEM-PLS Approach. Journal for International Business and Entrepreneurship Development, 8, 215-230. http://dx.doi.org/10.1504/JIBED.2015.070797

[26] Wiklund, J. and Shepherd, D. (2005) Entrepreneurial Orientation and Small Business Performance: A Configurational Approach. Journal of Business Venturing, 20, 71-91. http://dx.doi.org/10.1016/j.jbusvent.2004.01.001

[27] Hassim, A.A., Nizam, A., Talib, A. and Bakar, A.R.A. (2011) The Effects of Entrepreneurial Orientation on Firm Organisational Innovation and Market Orientation towards Firm Business Performance. International Proceedings of Economics Development \& Research, 10, 280-284.

[28] Kwon, Y.-C. (2010) Market Orientation of Korean MNC Subsidiaries and Their Performance in the Chinese and Indian Markets. International Marketing Review, 27, 179-199. http://dx.doi.org/10.1108/02651331011037511

[29] Shoham, A., Rose, G.M. and Kropp, F. (2016) Market Orientation and Performance: A Meta-Analysis. Marketing Intelligence \& Planning, 23, 435-454. http://dx.doi.org/10.1108/02634500510612627

[30] Gonzalez-Bentio, O., Gonzalez-Benito, J. and Munoz-Gallego, P.A. (2009) Role of Entrepreneurship and Market Orientation in Firms' Success. European Journal of Marketing, 43, 500-525. http://dx.doi.org/10.1108/03090560910935550 
[31] Green, K.W., Inman, R.A., Brown, G. and Hillman, W.T. (2005) Market Orientation: Relation to Structure and Performance. Journal of Business \& Industrial Marketing, 20, 276-284. http://dx.doi.org/10.1108/08858620510618110

[32] Gruber-Muecke, T. and Hofer, K.M. (2015) Market Orientation, Entrepreneurial Orientation and Performance in Emerging Markets. International Journal of Emerging Markets, 10, 560-571. http://dx.doi.org/10.1108/IJoEM-05-2013-0076

[33] Karani, S.R. and Bichanga, W.O. (2012) Effects of Total Quality Management Implementation on Business Performance in Service Institutions: A Case of Kenya Wildlife Services. International Journal of Research Studies in Management, 1, 59-76. http://dx.doi.org/10.5861/ijrsm.2012.v1i1.61

[34] Zelbst, P.J., Kenneth, W.G.J., Abshire, R.D. and Sower, V.E. (2013) Relationships among Market Orientation, JIT, TQM, and Agility. Industrial Management \& Data Systems, 110, 637-668. http://dx.doi.org/10.1108/02635571011044704

[35] Wang, C.-H. and Chen, S.-C. (2011) The Effect of the link Total Quality Management and Market Orientation On Hotel Performance. International Conference on Business and Economics Research, 1, 272-276.

[36] Pantouvakis, A. (2014) Market Orientation and Service Quality: Opponents or Colleagues. International Journal of Quality and Service Sciences, 6, 98-111. http://dx.doi.org/10.1108/IJQSS-02-2014-0014

[37] Ramayah, T., Samat, N. and Lo, M.-C. (2011) Market Orientation, Service Quality and Organizational Performance in Service Organizations in Malaysia. Asia-Pacific Journal of Business Administration, 3, 8-27. http://dx.doi.org/10.1108/17574321111116379

[38] Rauch, A., Wiklund, J., Lumpkin, G. and Frese, M. (2009) Entrepreneurial Orientation and Business Performance: An Assessment of Past Research and Suggestions for the Future. Entrepreneurship Theory Practice, 33, 761-787. http://dx.doi.org/10.1111/j.1540-6520.2009.00308.x

[39] Morris, M.H. (1998) Entrepreneurial Intensity: Sustainable Advantages for Individuals, Organisations and Societies. Quorum, Westport.

[40] Miller, D. and Friesen, P.H. (1983) Strategy-Making and Environment: The Third Link. Strategic Management Journal, 4, 221-235. http://dx.doi.org/10.1002/smj.4250040304

[41] Abiodun, T.S. and Rosli, M. (2014) The Mediating Effect of Reconfiguring Capabilities on the Relationship between Entrepreneurial Orientation and Export Performance of Small and Medium Enterprises. European Journal of Business and Management, 6, 345-358.

[42] Van Egeren, M. and O’Connor, S. (1998) Drivers of Market Orientation and Performance in Service Firms. Journal of Services Marketing, 12, 39-58. http://dx.doi.org/10.1108/08876049810202357

[43] Pelham, M. (1997) Market Orientation and Performance: The Moderating Effects of Product and Customer Differentiation. Journal of Business \& Industrial Marketing, 12, 276-296. http://dx.doi.org/10.1108/08858629710183257 